\title{
Meeting Up Millet Crop Water Requirements through Supplemental Irrigation in Semi-Arid Region of Borno State of Nigeria
}

\author{
A.B. Mustapha ${ }^{1,2^{*}}$ and Adzemi Mat Arshad ${ }^{1}$ \\ ${ }^{1}$ Soil Science Laboratory, School of Food Science and Technology, Universiti Malaysia Terengganu, 21030 \\ Kuala Terengganu, Terengganu, Malaysia \\ ${ }^{2}$ Department of Agricultural Technology, Ramat Polytechnic, Maiduguri Borno State, Nigeria
}

\begin{abstract}
The CROPWAT version 8.0 of the FAO was used to determine the seasonal pearl millet crop water requirement, effective rainfall and irrigation requirements as $445 \mathrm{~mm}, 248 \mathrm{~mm}$ and $145 \mathrm{~mm}$, respectively. The gravitational water which was in excess of field capacity lost to deep percolation was $219 \mathrm{~mm}$ while $246 \mathrm{~mm}$ of irrigation depth was used to supplement rainfall at different stages of growth. The 84mm of irrigation water applied during booting and grain-filling stages gave the highest yield of $2354.17 \mathrm{~kg}$ ha-1. Significant differences $(P<0.05)$ were observed for panicle length, stover weight, chaff weight and grain yield. It was observed that irrigation during booting and grain-filling stages produced more yield than the other treatments. It is therefore more suited to the dry sub-humid agroecological zone and its adoption can bring substantial yield increase of pearl millet per unit water used and land area. It should therefore be adopted to mitigate dry spells in other places with similar soil and climatic characteristics to supplement rainfed millet.
\end{abstract}

Keywords: Crop, Water, Irrigation

\section{Introduction}

Pearl millet (Pennisetum glaucum) is one of the four most important cereals (rice, maize, sorghum and millets) grown in the tropics. It is believed to have descended from a West African wild grass which was domesticated more than 40,000 years ago (NRC, 1996). It spread from there to East Africa and then to India. Today millet is a food staple for more than 500 million people. Areas planted with pearl millet are estimated at 15 million hectares annually in Africa and 14 million hectares in Asia.

The food value of pearl millet is high. Trials in India have shown that pearl millet is nutritionally superior for human growth when compared to maize and rice. The protein content of pearl millet is higher than maize and has a relatively high vitamin A content. In addition to tolerating hot and dry climates, pearl millet is able to produce reasonable yields on marginal soils, where other crops would fail. Low fertility and high salinity are frequent problems in millet producing areas.

Crop water requirement is defined as the depth of water needed to meet the water loss through evapotranspiration (ETcrop) of a disease - free crop, growing in large field under non-restricting soil conditions including soil water and fertility and achieving full production potential under the given growing environment (Doorenbos and Pruitt, 1996; Kumar, 2004; Michael, 2008). The amount of water required to compensate the evapotranspiration loss from the cropped field by a plant for its growth and maturity under field conditions, which includes the water supplied by rainfall, any irrigation and groundwater available to the plant. Crop water requirements encompass the total amount of water used in evapotranspiration.

Supplemental irrigation is defined by Kumar (2004) as, an irrigation applied to a crop facing water stress due to dry spells in a region where the crop cultivation is carried out using rainfall. Bridging the dry spells through supplemental irrigation of rainfed crops can be an interesting option to increase water productivity at production system level (Oweis and Hachum 2004). Supplemental irrigation in small holder farming systems can be achieved with water harvesting systems that collects local surface runoff in small storage structures. On-farm 
researches in semi arid locations in Kenya and Burkina Faso during 1998 to 2000 indicated significant scope of improving water productivity in rainfed farming through supplemental irrigation. Oweis and Hachum (2004) stated that supplemental irrigation is a highly efficient practice with great potential for increasing agricultural production and improving livelihoods in the dry rainfed areas.

Water-related problems in rainfed agriculture in water-scarce dry regions of Africa are often related to high intensity and large spatial and temporal variability of rainfall, rather than low cumulative volumes (Mahoo et al., 1999; Rockstrom et al., 1998; Sivakumar and Wallace, 1991). Rockstrom et al. (2002) concluded that, the overall result of unpredictable spatial and temporal rainfall patterns is a very high risk for meteorological droughts and intra seasonal dry spells which far exceed the occurrences of droughts. The existing evidence indicates that supplemental irrigation ranging from 50 to $200 \mathrm{~mm}$ per season is sufficient to mediate yield reduction by dry spells in most years and in rainfed systems.

\section{Materials and Method}

The experiment was conducted at Njimtilo village near Maiduguri along Kano road in Konduga Local Government Area of Borno State in Nigeria during 2015 rainfed millet cropping season. The climate is dry subhumid in nature as described by Ojanuga (2006). The mean daily temperature ranged between 23.6 and $34.80 \mathrm{C}$ during the cropping season (June to October) and annual average rainfall in the zone ranges between 508 to 762mm (NIMET, 2009). The soil in the study area was classified as Typic Haplustepts (Sadiq et al, 2012).

The land area of $500 \mathrm{~m} 2$ was marked out and was divided into 15 plots of $20 \mathrm{~m} 2(5 \mathrm{~m} \mathrm{x} 4 \mathrm{~m})$ with $1 \mathrm{~m}$ spacing between plots.

\subsection{Results}

Table 1 shows the crop evapotranspiration which was determined with the use of the CROPWAT version 8.0 using the following climatic variables; minimum and maximum temperatures (oC), relative humidity, daily sun shines hours, wind speed (Km day-1) and effective rainfall $(\mathrm{mm})$.

The water need of pearl millet calculated was $445.22 \mathrm{~mm}$ for the growing season and with effective rainfall (ER) determined was $248 \mathrm{~mm}$ hence the irrigation water requirement was $145 \mathrm{~mm}$. Considering application efficiency of $90 \%$, irrigation requirement is therefore $162 \mathrm{~mm}$. In order not to under-irrigate in the peak period as this period normally coincides with the growth stages of the crops that are most sensitive to water shortages FAO (1989) the maximum ETo $(6.26 \mathrm{~mm})$ was considered for all the growing stages as given in table 1 . To overcome the risk of water shortages in the peak months, it is possible to consider only at the months of peak irrigation water need and basing the determination of the interval on the peak period only.

TABLE I: Potential evapotranspiration derived from climatic data

\begin{tabular}{llll}
\hline Month & ETo $\left(\mathrm{mm} \mathrm{day}^{-1}\right)$ & No.of days & Cumulative ETo $(\mathrm{mm})$ \\
\hline July & 5.05 & 8 & 40.04 \\
August & 4.28 & 31 & 132.68 \\
September & 4.91 & 30 & 147.30 \\
October & 6.26 & 21 & 125.20
\end{tabular}

The crop water requirement for millet was less than the total rainfall received $(650.5 \mathrm{~mm})$ during the growing season but the effective rainfall $(248.8 \mathrm{~mm})$ was less than the crop water requirement for millet $(445.22 \mathrm{~mm})$ in the season. This shows that millet cannot produce optimum yield if rain-fed only.

Table 2 shows the monthly crop evapotranspiration and average monthly supplementary

irrigation requirements to meet up the crop water need.

The total available moisture (TAM) was $76 \mathrm{~mm}$ which is the water within the soil particles that can be extracted by the plant was obtained from the following formula; 


\begin{tabular}{lllllll}
\hline Month & Week & Stage & $\mathrm{K}_{\mathrm{c}}$ & $\mathrm{ET}_{\mathrm{c}}(\mathrm{mm} / \mathrm{day})$ & $\mathrm{ER}(\mathrm{mm} / \mathrm{day})$ & IWR $(\mathrm{mm} /$ day $)$ \\
\hline Jul & 3 & Initial & 0.20 & 8.60 & 33.2 & 0.0 \\
Aug & 1 & Dev. & 0.28 & 12.4 & 44.8 & 0.0 \\
Aug & 2 & Dev. & 0.63 & 26.3 & 48.4 & 0.0 \\
Aug & 3 & Mid & 0.95 & 46.3 & 40.3 & 6.0 \\
Sep & 1 & Mid & 0.99 & 46.3 & 30.8 & 15.5 \\
Sep & 2 & Mid & 0.99 & 48.4 & 24.0 & 24.4 \\
Sep & 3 & Late & 0.98 & 52.6 & 17.2 & 35.4 \\
Oct & 1 & Late & 0.77 & 45.5 & 8.9 & 36.6 \\
Oct & 2 & Late & 0.45 & 28.4 & 1.3 & 27.2 \\
& & & & 314.8 & 248.8 & 145.0 \\
\hline
\end{tabular}

$\mathrm{TAM}=$ FC-PWP.

This was calculated as

RAM $=$ pTAM

With $\mathrm{p}=0.55$ for millet crop (FAO, 1989) the RAM was approximately equals $42 \mathrm{~mm}$. Supplementary irrigation was applied whenever the TAM was depleted by $42 \mathrm{~mm}$ or when the remaining soil is moisture was $34 \mathrm{~mm}$ in order to bring the soil back to field capacity.

Table 3 shows the rainfall received, water loss and amounts of irrigation water applied to mitigate dry spell. The total rainfall received during 2015 rainy season at the study site was $650.5 \mathrm{~mm}$. The monthly distribution for July, August, September and November are also given in table 3.

Planting was done after receiving precipitation $51.1 \mathrm{~mm}$ on the 23rd July which considered enough to germinate pearl millet. The water holding capacity, the readily available water and the critical depletion of the soil were determined as $76 \mathrm{~mm}, 41.8 \mathrm{~mm}$ and $34.2 \mathrm{~mm}$ respectively. The soil moisture storage was kept above the allowable depletion by maintaining a balance of daily evapotranspiration of $6.26 \mathrm{~mm}$ and addition from the rainfall. The rainfall above $76 \mathrm{~mm}$ (the holding capacity of the soil) was considered lost. The water lost (LW), soil stored water (SSW) and irrigation water applied (IR) are recorded in column 3, 4 and 5 respectively.

Out of the $246 \mathrm{~mm}$ of supplementary irrigation applied, $124 \mathrm{~mm}$ was applied before the booting stage, $42 \mathrm{~mm}$ during booting stage and $42 \mathrm{~mm}$ during grain filling stage. The supplemental irrigation water of $84 \mathrm{~mm}$ applied during booting and grain filling stages produced the highest yield. Sharma, et al. (2010) reported that supplemental irrigation ranging from 50 to $200 \mathrm{~mm}$ per season is sufficient to mediate yield reduction by dry spells in most years and in rainfed systems.

The part of rainfall that was excess of the infiltration capacity of the soil were lost as surface runoff. The amounts of quantity water lost in the month of September and October were $99.52 \mathrm{~mm}$ and $53.84 \mathrm{~mm}$ respectively which were greater than the irrigation water applied in each case. This indicates that the problem dry spell is not related to the quantity of water received in the season but the distribution during the growing period. The yield of pearl millet is more closely related to the number of rain-days than to the seasonal rainfall total (Zakaria et ai 2012). This is in agreement with the claims that, water related problems in rainfed agriculture in water scarcity dry regions of Africa, are often related to high intensity and large spatial and temporal variability of rainfall, rather than low cumulative volumes (Mahoo et al., 1999; Rockstrom et al., 1998; Sivakumar and Wallace, 1991). Rockstrom et al. (2002) concluded that, the overall result of unpredictable spatial and temporal rainfall patterns is a very high risk for meteorological droughts and intra-seasonal dry spells which far exceed the occurrences of droughts. 
TABLE III: Calculated soil water balance (mm)

\begin{tabular}{|c|c|c|c|c|c|c|c|c|c|c|c|c|c|c|c|c|}
\hline & July & & & & August & & & & Septer & & & & Octol & & & \\
\hline & RF & LW & SSW & $\begin{array}{l}\text { IR } \\
\end{array}$ & $\mathrm{RF}$ & LW & SSW & IR & $\mathrm{RF}$ & LW & SSW & IR & $\mathrm{RF}$ & LW & SSW & IR \\
\hline 1 & & & & & 3.1 & & 64.60 & & 76.6 & 64.08 & 76.00 & & & & 53.96 & \\
\hline 2 & & & & & & & 58.34 & & & & 69.74 & & & & 47.70 & \\
\hline 3 & & & & & 37.7 & 20.04 & 76.00 & & & & 63.48 & & & & 41.44 & \\
\hline 4 & & & & & & & 69.74 & & & & 57.22 & & & & 75.18 & 40 \\
\hline 5 & 3.3 & & & & 10.0 & 3.74 & 76.00 & & 46.7 & 21.66 & 76.00 & & & & 68.92 & \\
\hline 6 & & & & & & & 69.74 & & & & 69.74 & & & & 62.66 & \\
\hline 7 & & & & & & & 63.48 & & & & 63.48 & & & & 56.40 & \\
\hline 8 & & & & & & & 57.22 & & 4.9 & & 62.12 & & & & 50.14 & \\
\hline 9 & & & & & & & 50.96 & & & & 55.86 & & & & 43.88 & \\
\hline 10 & 2.5 & & & & & & 44.70 & & 21.0 & & 70.60 & & & & 37.62 & \\
\hline 11 & & & & & 14.0 & & 52.44 & & & & 64.34 & & & & 73.36 & \\
\hline 12 & 0.7 & & & & 13.6 & & 59.78 & & & & 58.08 & & 40.8 & 31.90 & 76.00 & \\
\hline 13 & & & & & & & 53.52 & & & & 51.82 & & 28.2 & 21.94 & 76.00 & \\
\hline 14 & & & & & & & 47.26 & & & & 45.56 & & & & 69.74 & \\
\hline 15 & & & & & & & 41.00 & & & & 39.30 & & & & 66.48 & \\
\hline 16 & & & & & & & 76.00 & 42 & & & 75.04 & 42 & & & 60.22 & \\
\hline 17 & 9.7 & & & & 2.1 & & 71.84 & & & & 68.78 & & & & 53.96 & \\
\hline 18 & 3.7 & & & & & & 65.58 & & & & 62.52 & & & & 47.70 & \\
\hline 19 & & & & & & & 59.32 & & & & 56.26 & & & & 41.44 & \\
\hline 20 & 29.1 & & & & 1.8 & & 54.86 & & & & 50.00 & & 12.7 & & 75.18 & \\
\hline 21 & & & & & 0.7 & & 49.30 & & & & 43.74 & & & & 68.92 & \\
\hline 22 & & & & & & & 43.04 & & & & 37.48 & & & & 62.66 & \\
\hline 23 & 51.1 & & & & & & 76.00 & 40 & & & 73.22 & 42 & & & 56.40 & \\
\hline 24 & 1.4 & & 46.24 & & 29.1 & 22.84 & 76.00 & & & & 66.96 & & & & 50.14 & \\
\hline 25 & 14.9 & & 54.88 & & & & 69.74 & & & & 60.70 & & & & 43.88 & \\
\hline 26 & 8.7 & & 57.32 & & 3.0 & & 66.48 & & 0.6 & & 55.04 & & & & 37.62 & \\
\hline 27 & & & 51.06 & & & & 60.22 & & & & 48.78 & & & & & \\
\hline 28 & & & 44.80 & & & & 53.96 & & 41.0 & 13.78 & 76.00 & & & & & \\
\hline 29 & & & 38.54 & 42.00 & 10.3 & & 58.00 & & & & 69.74 & & & & & \\
\hline 30 & & & 74.02 & & & & 51.74 & & & & 66.48 & & & & & \\
\hline 31 & & & 67.76 & & 50.3 & 19.78 & 76.00 & & & & 60.22 & & & & & \\
\hline Total & 125.1 & & & 42 & 175.7 & 66.4 & & 82 & 190.8 & 99.52 & & 84 & 81.7 & 53.84 & & 40 \\
\hline
\end{tabular}

Note: RF = Rainfall, SSW = Soil stored water, IR = Irrigation water, LW = Gravitational water

Provision of supplemental irrigation of $84 \mathrm{~mm}$ during booting and grain filling stages (BGR) showed significant effect on the chaff weight, grain weight and stover weight indicating that supplemental irrigation is highly beneficial for pearl millet. Multiple irrigation (MTR) and irrigation at grain-filling stages (GFR) have statistically similar yields. 
TABLE IV: Effect supplemental irrigation on panicle thickness, Stover, chaff and grain weights of pearl millet

\begin{tabular}{|c|c|c|c|c|}
\hline Parameter & Panicle thickness $(\mathrm{cm})$ & $\begin{array}{l}\text { Stover weight }\left(\mathrm{Kg} \mathrm{ha}^{-}\right. \\
\left.{ }^{1}\right)\end{array}$ & $\begin{array}{l}\text { Chaff weight } \\
\left(\mathrm{Kg} \mathrm{ha}^{-1}\right)\end{array}$ & $\begin{array}{l}\text { Grain weight } \\
\left(\mathrm{Kg} \mathrm{ha}^{-1}\right)\end{array}$ \\
\hline BSR & 4.17 & $7682.32^{b}$ & $885.40^{b}$ & $1864.58^{b}$ \\
\hline GFR & 4.33 & $8294.58^{\mathrm{ab}}$ & $812.50^{\mathrm{bc}}$ & $2083.50^{\mathrm{ab}}$ \\
\hline BGR & 4.60 & $9520.35^{\mathrm{a}}$ & $1100.0^{\mathrm{a}}$ & $2354.17^{\mathrm{a}}$ \\
\hline MTR & 4.55 & $9414.76^{\mathrm{ab}}$ & $1075.0^{\mathrm{a}}$ & $2260.42^{\mathrm{ab}}$ \\
\hline RFR & 4.05 & $6023.83^{c}$ & $708.37^{\mathrm{c}}$ & $1395.83^{\mathrm{c}}$ \\
\hline GM & 4.34 & 8167.23 & 916.25 & 1991.70 \\
\hline SE & 0.190 & 541.142 & 48.640 & 129.601 \\
\hline
\end{tabular}

Note: Means followed by the same letters are not significantly different

$\mathrm{BSR}=$ Irrigation at booting stage, GFR= Irrigation at grain fill stage, BGR=Irrigation at booting and grain filling stages, MTR=Multiple irrigation and RFR=No Irrigation (rainfed) as control, GM =Grand mean.

The part of the total rainfall received during the growing season was lost as runoff or deep percolation during the 2015 raining season was $219.76 \mathrm{~mm}$ which is $34 \%$ of rainfall received during the season. This was as a result of very high intensity rainfall mostly poorly distributed coupled with high infiltration rate of the soil large quantity was drained below root zone. Consequently the risk of dry spells during the growing period of pearl millet. Supplementary irrigation during booting and grain filling stages increased yield by as much as $69 \%$ during the season which brought about the significant difference in both of grain yield and water use efficiency. The irrigation depth that produced this yield was $84 \mathrm{~mm}$ which was less than the rain water lost. It could be therefore concluded that the yield of pearl millet in dry sub-humid could be related to the number of rain-days of the rainy season rather than reduction in mean rainfall. Supplementary irrigation is a highly efficient practice with great potential for increasing agricultural production and improving livelihoods in the dry sub-humid rainfed areas. Droughts would have a very mild impact if farmers are equipped with supplemental irrigation and especially if combined with soil fertility management. Supplementary irrigation during booting and grain filling stages was more promising to be adopted in dry sub-humid agroecological conditions. Its adoption can bring about substantial yield of pearl millet per unit of water and land area. This will go a long way to increase farm income thus, reducing hunger and poverty.

\section{References}

[1] Doorenbos, J. and W.O. Pruitt (1996). Crop Water Requirements, Food and Agriculture Organization of the United Nations. Irrigation and Drainage Paper Rome Italy.

[2] FAO (1989). Food and Agricultural Organization. Irrigation in Africa in Figures. FAO Rome, Italy.

[3] Hassan, T.A. and E. I. Hessein (2015). Economics of Resource Use in Millet Production under Subsistence Farming System of South Darfur State of the Sudan. Journal of Science and Technology VOL. 5, NO. 1

[4] Kumar, D.M. (2004). Irrigation Water Management, Principles and Practice. Prentice Hall of India New Delhi.

[5] Mahoo, H.F., M.D.G. Young and O.B. Mizrai (1999). Rainfall variability and its implications for transferability of exponential results in semi-arid areas of Tanzania. Journal of Agricultural Science 2 92): 127-140.

[6] Michael, A.M. (2008). Irrigation Theory and Practice, 2nd Edition, VIKAS Publishing House, New Delhi, India $801 \mathrm{pp}$.

[7] NIMET, (2014). Field Data, Nigerian Meteorological Station, International Airport, Maiduguri.

[8] NRC, (1996). National Research Council. Lost Crops of Africa, Vol.1 Grains, National Academy Press, Washington DC. 
[9] Ojanuga, A.G. (2006). Agroecological zones of Nigeria Manual. National Special Programme for Food Security and FAO, Abuja, Nigeria.

[10] Oweis, T. and A. Hachum (2004). Water harvesting supplementary irrigation for improved water productivity of dry farming systems in West Asia and North Africa. In: New Direction for a Diverse Planet. Proceedings of the 4th International Crop Science Congress, Brisbane Australia, 26 September to 1 October 2004.

[11] Rockstorm, J., P.E. Jansson and J. Barron (1998). Seasonal rainfall pattern under runoff condition of sandy soil in Niger. On farm management and water balance modelling. Journal of Hydrology, 210: 68-92.

https://doi.org/10.1016/S0022-1694(98)00176-0

[12] Rockstorm, J., J. Barron and P. Fox (2002). Rainwater management for increased productivity among small holder farmers in drought-prone environments. Physics and Chemistry of the Earth, 27 pp. 949-959. https://doi.org/10.1016/S1474-7065(02)00098-0

[13] Sadiq, K.A., I.S. Dalatu and A.B. Mustapha (2012). The Effect of Incorporation of Saw Dust into Two Types of Organic Manure on the Growth and Yield Of Pearl Millet at Njimtilo Village in the Dry Sud-Humid Region of Borno State of Nigeria. 2nd International Conference on Environment Science and Biotechnology IPCBEE IACSIT Press, Singapore Vol. 48. 12

[14] Sharma, B.R., K.V. Rao, K.P.R. Vittal, Y.S. Ramakrishna and U. Amarasingh (2010). Estimating the Potential of Rainfed Agriculture in India: Prospects for Water Productivity Improvements.

[15] Sivakumar, M.V.K. and J.S. Wallace (1991). Soil water balance in Sudano Sahelian zone. In: Sivakumar, M.V.K., J.S. Wallace, C. Renard, C. Giroux (eds). Soil water balance in Sudano Sahelian Zone. Proceedings of International Workshop. Niamey, Niger 18-23 February 1991. A.H.S. Publication, No. 199. IAHS Press, Institute of Hydrology, Wallingford.

[16] Zakaria S., Nadhir Al-Ansari, Sven Knutsson and Mohammad Ezz-Aldeen (2012). Rain Water Harvesting and Supplemental Irrigation at Northern Sinjar Mountain, Iraq Journal of Purity, Utility Reaction and Environment Vol.1 No.3, pp121-141 